\title{
Prospective Science Teachers' Alternative Conceptions about the Chemistry Issues
}

\author{
Fethiye KARSLI ${ }^{1, *}$ \& Alipaşa AYAS ${ }^{2}$ \\ ${ }^{1}$ Giresun University, Giresun, TURKEY; ${ }^{2}$ Bilkent University, Ankara, \\ TURKEY
}

Received: 26.07.2012

Accepted: 05.11.2013

\begin{abstract}
The aim of this study is to determine alternative conceptions of prospective science teachers about the concepts of "Evaporation and Boiling", "Acid-Base Neutralization Reactions", "Dissolution and Factors Affecting Solubility", "Gas Laws", "Factors Affecting Reaction Rate" and "Electrochemical Cells". The sample of the study conducted according to a case study consisted of 97 third-year students enrolled in Department of Science Teaching Programme in Faculty of Education in Giresun University. As the data collection tool, twotier Chemistry Concept Tests (CCTs) developed by Karslı (2011) was used in this study. The results obtained from CCTs' data indicated that the prospective science teachers have various alternative conceptions about the chemistry concepts also reported in the literature and not mentioned in the literature. Within this research, possible causes of the alternative concepts determined in this study discussed, and some recommendations are presented for the elimination of these alternative concepts.
\end{abstract}

Key words: Alternative conceptions, prospective science teachers, chemistry issues.

DOI No: http://dx.doi.org/10.12973/nefmed211

\section{Summary}

Introduction: As a result of concept teaching, since 1980s two popular trends have been existed in chemistry/science education literature: (1) determining student conceptions or alternative conceptions (2) use of conceptual change theories to achieve a better conceptual understanding. Term 'alternative conception' means that students hold various conceptions which differ from the scientific one accepted by scientific community. In the literature, these ideas is referred to in various ways as "misconception" (Griffiths \& Preston, 1992; Nakhleh \& Krajcik, 1994), "alternative conceptions" (Gonzalez, 1997), “alternative frameworks" (Driver

\footnotetext{
* Corresponding author: Assist. Prof. Dr. Giresun University, Education Faculty, 28200, Giresun, TURKEY.

E-mail: fethiyekarsli@gmail.com
}

Note: This study is a part of Fethiye KARSLI phD dissertation 
\& Easley, 1978), "naive conceptions" (Fensham, 1988) and, "common sense concepts" or "spontaneous knowledge (Treagust, 1988). In fact, because alternative conceptions are not necessarily spontaneous ideas, they may result from instruction or teachers or the textbooks or the discrepancy between daily language (Çalık, 2006; Ünal \& Coştu, 2005) and scientific language or students' social envirments (Ayas \& Demirbaş, 1997; Finley et al., 1982). Whatever the reason of the alternative concepts, to determine them information to higherlevel learning negatively affecting is a very important step in further studies.

The aim of this study is to determine alternative conceptions of prospective science teachers about the concepts of "Evaporation and Boiling", "Acid-Base Neutralization Reactions", "Dissolution and Factors Affecting Solubility", "Gas Laws", "Factors Affecting Reaction Rate" and "Electrochemical Cells". The following research questions guide this study: (1) What are prospective science teachers have alternative concepts in the topics discussed? (2) What are the possible causes of determined alternative concepts in this study.

\section{Methodology}

Research Method: The case study method one of the descriptive research was used in this study, which is a method of dealing with all aspects of a situation was used.

Studying Group: The sample of the study consisted of 97 third-year students enrolled in four different classes of Department of Science Teaching Programme in Faculty of Education in Giresun University.

Data Collection Tools:In the research, the data were gathered by means of two - tier Chemistry Concept Tests (CCTs), one of the frequently used tests to get information about students' alternative conceptions, developed by Karslı (2011).

Analysis of Data: In the analysis of two-stage questions, it is observed that students' responses are generally categorized and scored in the literature (Abraham et al, 1992; Çalık, 2006; Çalık et al, 2010; Haidar \& Abraham, 1991; Marek, 1986). In the research, the first stage of CCTs were analyzed under three categories as right choices, wrong choices and blank, and the second stage were analyzed under four categories as correct explanation, partially correct explanation, alternative join concept explanation / incorrect explanation and blank. Then the frequency (f) of alternative concepts in students have been identified.

Results and Discussion: Although prospective science teachers have learned chemistry topics which are covered in the research at both high school and university I-II, the results obtained from CCTs' data indicated that they have still various alternative conceptions about the chemistry concepts also reported in the literature and not mentioned in the literature. In the 
research, it is observed that students have I) 23 different alternative concepts about the evaporation and boiling; II) 9 different alternative concepts about the acid-base neutralization reaction; III) 13 different alternative concepts about dissolution and factors affecting solubility; IV) 12 different alternative concepts about the gases laws; V) 15 different alternative concepts about the factors affecting reaction rate; VI) 12 different alternative concepts about the electrochemical cells.

Suggestions: Future researchers can organize training intended to remove students' alternative conceptions about the chemistry issues. Also similar studies can be made to uncover the different grade students' prior knowledge related to these concepts. The research shouldn't be limited with these concepts that are subject of the study. Prior knowledge of students about the other chemistry concept taking place in chemistry programs can be determined. Finally, students can learn the chemistry concepts by making experiments and using methods enriched with different conceptual methods and technics at the laboratories which is usually taught to places to effective learning and conceptual change in a positive direction. 


\title{
Fen Bilgisi Ögretmen Adaylarının Kimya Konularında Sahip Oldukları Alternatif Kavramlar
}

\author{
Fethiye KARSLI ${ }^{1,+}$, Alipaşa AYAS ${ }^{2}$ \\ ${ }^{1}$ Giresun Üniversitesi, Giresun,TÜRKİYE; ${ }^{2}$ Bilkent Üniversitesi, Ankara, \\ TÜRKİYE
}

Makale Gönderme Tarihi: 26.07.2012

Makale Kabul Tarihi: 05.11.2013

\begin{abstract}
Özet - Bu çalışmanın amacı fen bilgisi öğretmen adaylarının "Buharlaşma ve Kaynama", "Reaksiyon Hızına Etki Eden Faktörler”, “Asit-Baz Nötrleşme Reaksiyonları”, "Çözünme ve Çözünürlüğe Etki Eden Faktörler”, "Gaz Yasaları" ve "Elektrokimyasal Piller" konu başlıklarındaki kavramlarında sahip oldukları alternatif kavramlarını belirlemektir. Özel durum çalışmasına uygun olarak yürütülen bu araştırmanın örneklemi, Giresun Üniversitesi, Eğitim Fakültesi Fen Bilgisi Öğretmenliği Programında öğrenim gören toplam 97 üçüncü sınıf öğretmen adayından oluşmaktadır. Veri toplama aracı olarak Karslı (2011) tarafından geliştirilen iki aşamalı kimya kavram testi (KIKKAT) kullanılmıştır. Araştırmada fen bilgisi öğretmen adaylarının araştırma kapsamında ele alınan konularda literatürde rapor edilen alternatif kavramların yanı sıra literatürde rastlanmayan alternatif kavramlara da sahip oldukları sonucuna ulaşılmıştır. Araştırma kapsamında tespit edilen alternatif kavramların olası nedenleri tartışılarak, bu alternatif kavramlarının giderilmesine yönelik bazı öneriler sunulmuştur.
\end{abstract}

Anahtar Kavramlar: Alternatif kavramlar, fen bilgisi öğretmen adayları, kimya konuları

\section{Giriş}

Kavram öğretimine ve kavramların anlaşılmasına yönelik yapılan birçok çalışmada; öğrencilerin fen bilimlerindeki kavramların anlaşılmasında güçlük çektikleri (Ayas ve Demirbaş, 1997; Finley vd., 1982), gerek günlük deneyimleri sırasında (Çalık, 2006; Ünal ve Coştu, 2005), gerekse öğretim öncesinde ve sırasında bilimsel olarak doğru kabul edilen kavramlara aykırı kavramlar geliştirebildikleri gözlenmektedir. Literatürde öğrencilerin bilimsel olarak doğru kabul edilen kavramların haricinde geliştirdikleri bu kavramlar; "kavram yanılg1sı" (misconception) (Griffiths ve Preston, 1992; Nakhleh ve Krajcik, 1994),

\footnotetext{
† İletişim: Yrd. Doç.Dr., Giresun Üniversitesi, Eğitim Fakültesi, 28200, Giresun, TÜRKIYE.

E-mail: fethiyekarsli@gmail.com
}

Not: Bu çalışma Fethiye KARSLI'nın doktora tezinin bir parçasıdır. 
"alternatif kavramlar" (alternative conceptions) (Gonzalez, 1997), "alternatif yapılar" (alternative frameworks) (Driver ve Easley, 1978), "öznel fikirler” (naive conceptions), (Fensham, 1988) ve "genel duyu kavramları" (common sense concepts) ya da "kendiliğinden oluşan bilgiler” (spontaneous knowledge) (Treagust, 1988) gibi çeşitli şekillerde anılmaktadır. $\mathrm{Bu}$ çalışmada bilimsel olarak doğru kabul edilen kavramlara aykırı olan kavramlar için alternatif kavram terimi kullanılmıştır. Öğrencilerin bilimsel kavramlar geliştirememelerinde; a) öğrencilerin öğrenme ortamlarına birtakım yanlış inançlarla gelmesi, b) öğretimin etkili bir şekilde düzenlenmemesi, c) ders kitaplarında ve/veya diğer öğretim kaynaklarında yanlış anlaşılmaya neden olabilecek ifadelerin olması, d) öğretmenlerin ders anlatırken yanlış ifadeler kullanması, e) öğretim sürecinde tartışılan alternatif fikirlerin ve sunulan bilimsel açıklamaların öğrenci tarafından yanlış yorumlanması, f) laboratuarlarda deney yapılmadığı zamanlarda öğrencilerin bilgiyi kendilerinin keşfetmesine imkân sunulmaması vs. neden gösterilebilir. Nedeni her ne olursa olsun öğrencilerin daha üst düzey bilgileri öğrenmelerine olumsuz yönde etki eden alternatif kavramların tespit edilmesi, bunların değiştirilmesine yönelik yapılacak çalışmalarda oldukça önemli bir adımdır.

Alternatif kavramların belirlenmesi, kavramsal değişim çalışmalarının temelini oluşturmasından dolayı literatürde özellikle kimya alanında eğitimin çeşitli kademelerindeki öğrencilerin alternatif kavramlarının belirlenmesine yönelik birçok araştırma yapılmıştır. Bu çalışmaların örneklemleri incelendiğinde ilköğretim (Örneğin; Paik vd., 2004; Tytler, 2000), lise (Demerouti vd., 2004; Koray, Akyaz ve Köksal, 2007; Lin vd., 2000; Nakhleh, 1994; Sheppard, 2006), üniversite öğrencilerinin (Canpolat vd., 2006; Kalın ve Arıkı1, 2010; Lin vd., 2000) ve hatta öğretmenlerin (Chou, 2002; Drechsler ve Driel, 2008; Furio-Mas vd., 2005) bile ele alınan konularda çeşitli alternatif kavramlara sahip oldukları görülmektedir. Özellikle öğretmen ve öğretmen adaylarının kimyanın çeşitli konularında alternatif kavramlara sahip olması ilerisi için endişe verici bir durumdur. Çünkü mevcut öğretmenler ve öğretmen adayları öğretmen olduklarında bu alternatif kavramları kendi öğrencilerine taşıyabilmektedir (Ebenezer ve Erickson, 1996). Bu bağlamda kimyanın farklı konularında öğretmen eğitimi programlarında öğrencilerde var olan alternatif kavramların belirlenmesi, onların bu alternatif kavramlarının giderilmesi ve olumlu yönde kavramsal değişim gerçekleştirilmesi için oldukça gereklidir.

Literatürde öğrencilerin alternatif kavramlarının belirlenmesine yönelik araştırmalar incelendiğinde daha çok kimya konularından elektrokimya (Garnett ve Treagust, 1992a; Yılmaz vd., 2002), çözünürlük (Çalık vd., 2006; Kalın ve Arıkı1, 2010; Özden, 2009), 
reaksiyon hızı (Çakmakçı vd., 2006; Kolomuç ve Tekin, 2011) gibi tek bir konuya ya da kavrama yoğunlaştıkları dikkat çekmektedir. Fakat gelecek neslin kavramsal gelişiminin şekillenmesinde önemli bir etkisi olacak olan öğretmen adaylarının kimyanın farklı konuları ile ilgili alternatif kavramlarını rapor eden araştırmalar sınırlıdır. Öğrencilerde kimyanın çeşitli konularında alternatif kavramlarının olması, onların temel kavramlar üzerine inşa edeceği daha ileri düzeydeki kimya konularını anlamalarını, öğretmelerini ve bunun sonucunda da anlamlı öğrenmenin gerçekleşmesini güçleştirmektedir (Nakhleh, 1992). Dolayısıyla kimya konularında fen bilgisi öğretmen adaylarının alternatif kavramlarının belirlenmesi ve sonuçlarının paylaşılması ileride bu alternatif kavramların giderilmesine yönelik yapılacak olan çalışmalara da 1şık tutacaktır. Ayrıca öğrencilerde öğretmen kaynaklı oluşabilecek alternatif kavramların erkenden önüne geçilmesinde bir adım olacaktır.

$\mathrm{Bu}$ çalışmanın amacı öğretmen eğitimi programında kimya ile ilgili dersleri alan fen bilgisi öğretmen adaylarının kimyanın "Buharlaşma ve Kaynama", "Reaksiyon Hızına Etki Eden Faktörler”, “Asit-Baz Nötrleşme Reaksiyonları”, “Çözünme ve Çözünürlüğe Etki Eden Faktörler”, "Gaz Yasaları" ve "Elektrokimyasal Piller” konularında sahip oldukları alternatif kavramlarını belirlemektir. Bu amaçla aşağıdaki alt problemler üzerine odaklanılmıştır.

1. Fen bilgisi öğretmen adaylarının kimyanın çeşitli konularında ele alınan kavramlarda sahip olduğu alternatif kavramları nelerdir?

2. Araştırma kapsamında tespit edilen alternatif kavramların olası nedenleri nelerdir?

\section{Yöntem}

$\mathrm{Bu}$ araştırmada fen bilgisi öğretmen adaylarının öğrenilmiş çeşitli kimya konularındaki kavramları nasıl algıladıklarının ve sahip oldukları alternatif kavramların neler olduğunun belirlenmesi amaçlanmaktadır. $\mathrm{Bu}$ amaca yönelik olarak araştırmada betimsel araştırma türlerinden özel durum yöntemi kullanılmıştır. Araştırılan bir konunun derinlemesine incelenmesine firsat sunan bu yöntem nitel ve nicel verilerin toplanmasına imkan sunmaktadır. Bu yöntem ile araştırılan gruba herhangi bir müdahale yapılmadan mevcut durum ortaya çıkarılmaya çalışılır (Çepni, 2009; Yıldırım ve Şimşek, 2008). Bu araştırmada özel durum çalışması araştırma sürecinde herhangi bir değişiklik yapılmadan fen bilgisi öğretmen adaylarının sahip oldukları alternatif kavramların neler olduğunun derinlemesine inceleme imkanı veren bir yöntem olmasından dolayı tercih edilmiştir.

\section{Örneklem}


Araştırmanın örneklemini, 2010-2011 eğitim-öğretim y1lında, Giresun Üniversitesi Eğitim Fakültesi Fen Bilgisi Öğretmenliği Programında öğrenim gören yaşları 20 ile 24 arasında değişen toplam 97 üçüncü sınıf öğretmen adayı oluşturmaktadır. Araştırmaya katılan öğrenciler, 1. sınıfta genel kimya I-II ve genel kimya laboratuarı I-II derslerini, 2. sınıfta ise analitik kimya ve organik kimya derslerini başarı ile tamamlamıştır.

\section{Veri Toplama Aracı}

Literatürde, öğrencilerin bilimsel kavramlar hakkındaki düşüncelerini belirlemek için kavram haritaları (Hazel \& Prosser, 1994), tahmin-gözlem-açıklama (TGA) (Liew \& Treagust, 1994), mülakat (Abdullah \& Scaife, 1997; Osborne \& Gilbert, 1980; Osborne \& Cosgrove, 1983), çizimler (Smith \& Metz, 1996), kelime ilişkilendirme (Maskill \& Cachapuz, 1989), test yöntemi (White \& Gustone, 1992) ve iki aşamalı testler (Karslı ve Çalık, 2012; Sun, 2009; Şahin ve Çepni, 2011; Tüysüz, 2009; Treagust ve Chandrasegaran, 2007) kullanılmıştır. Bu araştırmada, öğrencilerin alternatif kavramları hakkında bilgiye ulaşmak için sıklıkla kullanılan testlerden, Karslı (2011) tarafından geliştirilen, iki aşamalı kimya kavram testi (KİKAT) veri toplama aracı olarak kullanılmıştır. KIKKAT "Buharlaşma ve Kaynama" ve "Reaksiyon Hızına Etki Eden Faktörler" konularının her birisi ile ilgili 7, "AsitBaz Nötrleşme Reaksiyonları”, “Çözünme ve Çözünürlüğe Etki Eden Faktörler”, "Gaz Yasaları" ve "Elektrokimyasal Piller" konularının her birisi ile ilgili 6 madde olmak üzere toplam 38 maddeden oluşmaktadır. KİKAT'in ilk aşaması çoktan seçmeli yapıda olup, beş seçeneklidir. Seçeneklerden birisi doğru olup, diğerleri ise ilgili konularda literatürden tespit edilmiş alternatif kavramları içermektedir. Testin ikinci aşaması, öğrencinin ilk kısımda işaretlediği seçeneği, işaretleme gerekçesinin belirtilmesinin istendiği açık uçlu kısımdır. Araştırmada kullanılan KİKAT’in kapsam ve görünüş geçerliliği için ikisi kimya eğitiminde öğretim üyesi ve biri kimya eğitiminde araştırma görevlisi olmak üzere toplam 3 kimya eğitimcisinin ve 2 lise kimya öğretmeninin görüşlerinden faydalanılmıştır. İki aşamalı olan sıralamalı ölçek çeşidine giren KİKAT’in iç tutarlılık güvenirlik analizi, Cronbach alfa güvenirlik katsayısı hesaplanarak yapılmıştır. Geliştirilen bu kavram testlerinden "Buharlaşma ve Kaynama” konuları ile ilgili maddelerin Cronbach alfa güvenirlik katsayısı 0,77 olarak hesaplanmıştır. “Asit-Baz Nötrleşme Reaksiyonları”, “Çözünme ve Çözünürlüğe Etki Eden Faktörler", “Gaz Yasaları", "Reaksiyon Hızına Etki Eden Faktörler” ve "Elektrokimyasal Piller" konuları ile ilgili maddelerin Cronbach alfa güvenirlik katsayıları sırası ile $0,83,0,71$, 0,60, 0,65 ve 0,80 olarak hesaplanmıştır. Ayrıca, bu 6 ayrı kimya konusunu içeren 38 maddelik test, bütün olarak düşünüldüğünde ise testin Cronbach alfa güvenirlik katsayısı 0,79 
olarak hesaplanmıştır. Test ikiye bölünerek öğrencilere farklı iki günde uygulanmış olup, verilerin toplanmas1 2,5 saat sürmüştür. Şekil 1'de buharlaşma konusunda KİKAT'ten örnek bir soru sunulmuştur.

\section{Şekil 1}

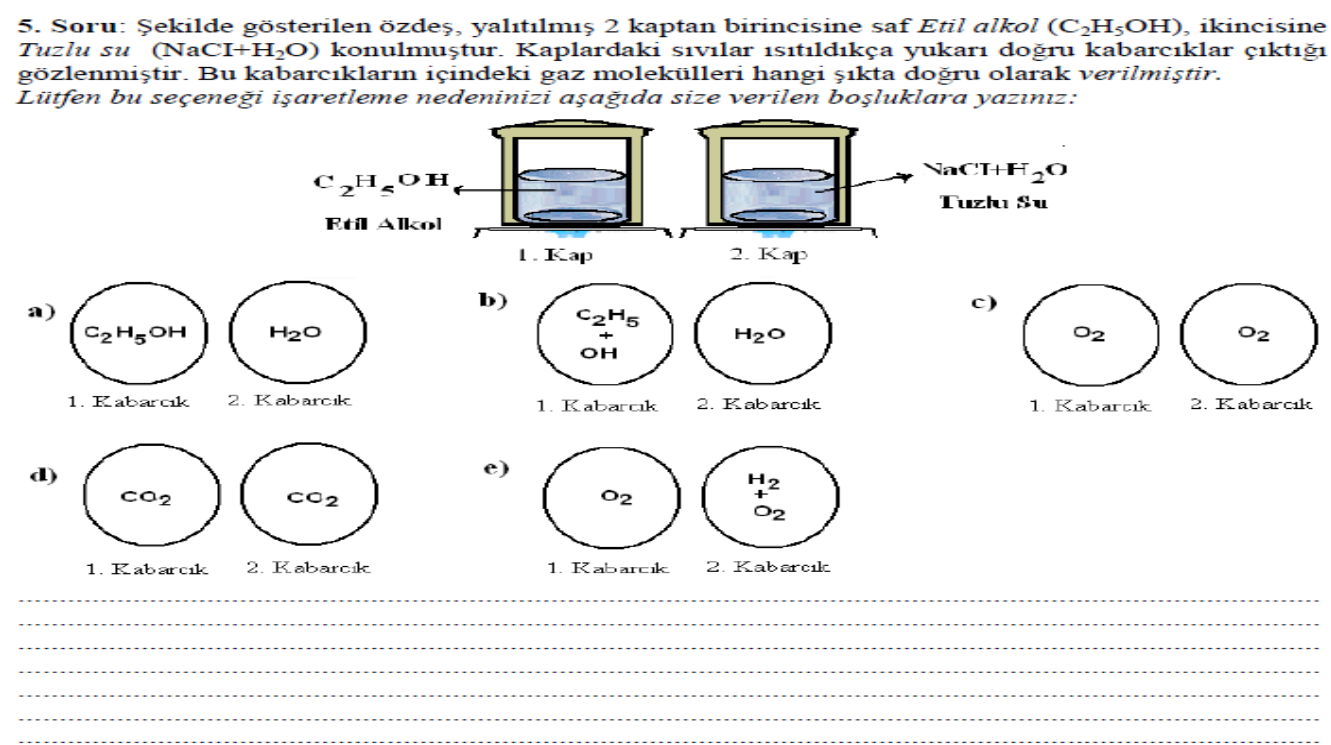

Buharlaşma Konusunda KIKAT’te Yer Alan Örnek Bir Soru

\section{Verilerin analizi}

Literatürde iki aşamalı soruların analizinde genel olarak öğrenci cevaplarının kategorilere ayrılarak puanlandığı görülmektedir (Abraham vd., 1992; Çalık, 2006; Çalık vd., 2010; Haidar ve Abraham, 1991; Marek, 1986). Bu araştırma kapsamında KİKAT’ten elde edilen verilerin analizinde testin ilk aşamasında öğrenci cevapları Doğru Seçenek (DS), Yanlış Seçenek (YS) ve Boş (B) şeklinde üç kategori altında analiz edilmiştir. Testin ikinci aşaması öğrencilerin ilk aşamada verilen seçeneklerden hangisini neden seçtiğini ayrıntılı açıklamaları istenen açık uçlu kısımdır. Bu yüzden, öğrencilerin ikinci aşamada yapmış oldukları açıklamalar; Doğru Açıklama (DA), Kısmen Doğru Açıklama (KDA), Alternatif Kavramlı Açıklama/Yanlış Açıklama (AKA) ve Boş/İlişkisiz Açıklama (B) şeklinde kategorilere ayrılarak, öğrenci cevaplarından bilimsel doğrularla çelişen ifadeler (AKA kategorisine giren cevaplar) tespit edilmiş ve bu ifadeleri katılımcıların ne sıklıkla kullandıkları (frekans) hesaplanmıştır. Öğrencilerin ikinci aşamaya verdikleri cevaplar araştırmadan bağımsız, kimya eğitiminde doktora yapan, 2 kimya eğitimcisi tarafindan da kategorileştirilerek araştırmacılar arasındaki uyuşma oranı da hesaplanmıştır. Burada eğer öğrencilerin yaptığı açıklamalar en az iki araştırmacı tarafından AKA kategorisine sokulduysa, o öğrencinin ilgili konuda belirttiği alternatif kavrama sahip olduğu yorumu yapılmıştır. AKA kategorisine giren cevapların analizinde üç araştırmacının değerlendirmeleri arasındaki uyuşma \% 78 olarak hesaplanmıştır. Ölçüm aracı kullanılarak yapılan 
değerlendirmelerde gözlemciler arasındaki uyuşmanın en az \% 70 düzeyinde olması istenmektedir (Şencan, 2005). Bu durum öğrenci cevaplarını değerlendiren araştırmacılar arasında anlamlı bir fark olmadı̆̆ı şeklinde yorumlanmaktadır.

\section{Bulgular}

Fen bilgisi öğretmen adaylarında çeşitli kimya konularında tespit edilen alternatif kavramlar tablolar aracılığıyla sunulmuştur. Tablolarda her bir konudaki alternatif kavramlar, tanımlayıcı kategoriler altında toplanmış ve bunlara numaralar $(\mathrm{N})$ verilmiştir. Ayrıca, bu alternatif kavramların öğrencilerde bulunma sıklığı (f - frekansı) belirtilmiştir. Tablolar 1-5'te “*” işareti ile belirtilen ifadeler, literatürde rastlanmayan fakat bu çalışmada tespit edilen alternatif kavramlardır.

\section{Buharlaşma ve Kaynama Konusundaki Alternatif Kavramlar}

KİKAT'in buharlaşma ve kaynama ile ilgili 1.-7. sorularına öğrencilerin verdikleri cevaplardan tespit edilen alternatif kavramlar Tablo 1'de sunulmaktadır.

Tablo 1 "Buharlaşma ve Kaynama” Konusunda Tespit Edilen Alternatif Kavramlar

\begin{tabular}{|c|c|c|c|}
\hline $\begin{array}{l}\text { Tanımlayıcı } \\
\text { Kategoriler }\end{array}$ & $\mathbf{N}$ & Öğrencilerin Alternatif Kavramları & f \\
\hline Buharlaşma & 1 & Sicaklık artışı olmazsa buharlaşma olmaz. & 5 \\
\hline \multirow[t]{8}{*}{ ve kaynama } & 2 & $\begin{array}{l}\text { Bir buharlaşma işleminin gerçekleşmesi için sıvının kaynayarak moleküllerinin } \\
\text { birbirinden ayrılması gerekir. }\end{array}$ & 11 \\
\hline & 3 & $\begin{array}{l}\text { Su buharlaşırken fiziksel değişime, etil alkol ise kimyasal değişime uğrayarak } \\
\text { bileşenlerine ayrılır. }\end{array}$ & 2 \\
\hline & 4 & $\begin{array}{l}\text { Buharlaşma her sıcaklıkta olduğu için sıvının tümünde, kaynama ise sadece sıvının } \\
\text { yüzeyinde olur. }\end{array}$ & 15 \\
\hline & 5 & $\begin{array}{l}\text { Su buharlaşırken } \mathrm{H}_{2} \mathrm{O} \text {, kaynarken } \mathrm{H}_{2} \text { ve } \mathrm{O}_{2} \text { şeklinde ayrışarak sıvıyı gaz halinde terk } \\
\text { eder. }\end{array}$ & 8 \\
\hline & 6 & Dışarıdan 1Sı alan bir sıvı buharlaşırken molekül içi bağlar kopar. & 32 \\
\hline & 7 & $\begin{array}{l}\text { Etil alkol buharlaşırken kabarcıklarda } \mathrm{O}_{2} \text { gazı, tuzlu su buharlaşırken } \mathrm{H}_{2} \mathrm{O} \\
\text { bileşenlerine ayrıldığından kabarcıklarda } \mathrm{H}_{2} \mathrm{ve}^{\mathrm{O}} \mathrm{O}_{2} \text { gazı vardır. }\end{array}$ & 8 \\
\hline & 8 & Isı verildikçe etil alkol ve tuzlu su kabarcıklarının içinden $\mathrm{CO}_{2}$ gazları çıkar. & 2 \\
\hline & 9 & $\begin{array}{l}\text { Kaynama esnasında isı verilmeye devam edilirse maddenin kinetik enerjisi ve } \\
\text { sıcaklı̆g artar. }\end{array}$ & 31 \\
\hline \multirow{10}{*}{$\begin{array}{l}\text { Kaynama } \\
\text { noktasını } \\
\text { etkileyen } \\
\text { faktörler }\end{array}$} & 10 & $\begin{array}{l}\text { Bir sıvının deniz seviyesinden uzak ya da yakın bir yerde kaynatılması onun } \\
\text { kaynama noktasını }(\mathrm{KN}) \text { değil kaynama süresini etkiler. KN kaynatılan yerden } \\
\text { etkilenmez. Mesela su her yerde } 100^{\circ} \mathrm{C}^{\prime} \text { de kaynar. }\end{array}$ & 33 \\
\hline & 11 & $\begin{array}{l}\text { Buhar basıncı ile KN doğru orantılıdır. Buhar basıncı arttıkça, tanecikler arası çekim } \\
\text { kuvveti (KN)'de artar. }\end{array}$ & 8 \\
\hline & 12 & Sıvının ilk sıcaklığı o sıvının KN'sini etkiler.* & 4 \\
\hline & 13 & Isı kaynağının güçlü olması KN’yi arttırır. & 7 \\
\hline & 14 & Sivının saflı̆̆ 1 KN'yi etkilemez. & 4 \\
\hline & 15 & $\begin{array}{l}\text { Saf bir sıvıya uçuculuğu kendininkinden az katı bir madde eklendiğginde KN azalır. } \\
\text { Örneğin, yemeğin hemen kaynaması için tuz koyarız, tuz katmak KN'yi düşürür. }\end{array}$ & 13 \\
\hline & 16 & Kabın açık ya da kapalı olması KN'yi etkilemez. & 7 \\
\hline & 17 & Kapalı kapta KN daha düşüktür. & 3 \\
\hline & 18 & Diş basınç azalırsa KN artar. & 4 \\
\hline & 19 & Yükseğe çıkıldıkça basınç artar, sıvının KN'si artar. & 7 \\
\hline
\end{tabular}




\begin{tabular}{cclll}
\hline \multirow{3}{*}{ Buhar } & 20 & Aynı bölgede bütün sıvıların KN aynıdır. & 3 \\
basıncı & 21 & Kaynama anında sıvının buhar basıncı açık hava basıncından farklıdır. & 3 \\
& 22 & $\begin{array}{l}\text { Aynı sıcaklıkta suyun buhar basıncı deniz seviyesinde yükseklere göre daha fazladır. } \\
\text { Aynı ortamda birbirinden farklı sıvıların kaynama anındaki buhar basınçları sıvılar }\end{array}$ & 5 \\
& 23 & \begin{tabular}{l} 
farklı olduğu için farklıdır. \\
\hline
\end{tabular}
\end{tabular}

N: Öğrencilerde tespit edilen alternatif kavramların numaraları; f: Frekans; *: Literatürde rastlanmayan alternatif kavramlar

Tablo 1 incelendiğinde, buharlaşma ve kaynama konusunda öğrencilerin 23 farklı alternatif kavrama sahip olduğu görülmektedir. Bu alternatif kavramlar, "buharlaşma ve kaynama", "kaynama noktasına etki eden faktörler" ve "buhar basıncı" kategorilerinde yer almaktadır. Öğrencilerde en fazla sıklıkta 6, 9 ve 10 numaralı alternatif kavramların, en az sıklıkta ise 3 ve 8 numaralı alternatif kavramların olduğu tespit edilmiştir.

\section{Asit-Baz Nötrleşme Reaksiyonları Konusundaki Alternatif Kavramlar}

KİKAT'in asit-baz nötrleşme reaksiyonları ile ilgili 8.-13. sorularına öğrencilerin verdikleri cevaplardan tespit edilen alternatif kavramlar Tablo 2'de sunulmaktadır.

Tablo 2 “Asit-Baz Nötrleşme Reaksiyonları” Konusunda Tespit Edilen Alternatif Kavramlar

\begin{tabular}{|c|c|c|c|}
\hline $\begin{array}{l}\text { Tanımlayıcı } \\
\text { Kategoriler }\end{array}$ & $\mathbf{N}$ & Öğrencilerin Alternatif Kavramları & $\mathbf{f}$ \\
\hline \multirow[t]{9}{*}{ Nötrleşme } & 1 & $\begin{array}{l}\text { Sadece kuvvetli asitle kuvvetli baz tepkimeye girdiğinde ya da ikisi de zayıf } \\
\text { olduğunda nötrleşme tepkimesi gerçekleşir. }\end{array}$ & 33 \\
\hline & 2 & $\begin{array}{l}\text { Nötrleşme tepkimesi sonucu her zaman bir nötr tuz ve su oluşur ve pH her zaman } \\
\text { 7'dir. }\end{array}$ & 16 \\
\hline & 3 & $\begin{array}{l}\text { Renk dönüşümünün olduğu nokta: nötrleşmenin olduğu, pH'nın her zaman } 7 \text { ve } \\
\text { ortamın nôtr olduğu yerdir. }\end{array}$ & 28 \\
\hline & 4 & $\begin{array}{l}\text { Kuvvetli asit çözeltisine zayıf bir baz çözeltisi ilave edilirse tam nötrleşme } \\
\text { gerçekleşmez. Tam nötrleşme kuvvetli asit ile kuvvetli baz arasında olur. }\end{array}$ & 28 \\
\hline & 5 & Kuvvetli asitle zayıf baz tam nötrleșmez ama pH değeri 7 olur. & 2 \\
\hline & 6 & Üründe tuz oluşmuş bütün tepkimeler nötrleşme tepkimesidir.* & 3 \\
\hline & 7 & Asit ve baz titrasyonunda renk değișimi gerçekleştiği için bu fiziksel bir olaydır. & 1 \\
\hline & 8 & $\begin{array}{l}\text { Asit ve baz karıştırıldığında kimyasal bir tepkime değil nötrleşme tepkimesi } \\
\text { gerçekleşir. }\end{array}$ & 1 \\
\hline & 9 & İndikatörler nötrleșmenin daha hızlı gerçekleșmesini sağlar. & 2 \\
\hline
\end{tabular}

Tablo 2 incelendiğinde, asit-baz nötrleşme reaksiyonları konusunda öğrencilerin 9 farklı alternatif kavrama sahip olduğu görülmektedir. Bu alternatif kavramlar "nötrleşme" kategorisinde yer almaktadır. Öğrencilerde en fazla sıklıkta 1, 3 ve 4 numaralı alternatif kavramların, en az sıklıkta ise 7 ve 8 numaralı alternatif kavramların olduğu belirlenmiştir.

\section{Çözünme ve Çözünürlüğe Etki Eden Faktörler Konusundaki Alternatif Kavramlar}

KİKAT'in çözünme ve çözünürlüğe etki eden faktörler ile ilgili 14.-19. sorularına öğrencilerin verdikleri cevaplardan tespit edilen alternatif kavramlar Tablo 3'te sunulmaktadir. 
Tablo 3 incelendiğinde, çözünme ve çözünürlüğe etki eden faktörler konusunda öğrencilerin 13 farklı alternatif kavrama sahip olduğu gözlenmektedir. Öğrencilerde en fazla s1klıkta 6 numaralı alternatif kavramın, en az s1klıkta ise 2 ve 10 numaralı alternatif kavramların olduğu belirlenmiştir.

Tablo 3 “Çözünme ve Çözünürlüğe Etki Eden Faktörler” Konusunda Tespit Edilen Alternatif Kavramlar

\begin{tabular}{|c|c|c|c|}
\hline $\begin{array}{l}\text { Tanımlayıcı } \\
\text { Kategoriler }\end{array}$ & $\mathbf{N}$ & Öğrencilerin Alternatif Kavramları & f \\
\hline \multirow{4}{*}{ Çözünme } & 1 & Tuz, su içerisinde çözünür ve yeni bir bileşik oluşur. & 2 \\
\hline & 2 & $\mathrm{NaCl}$ molekülleri su içinde çözünürken rastgele dağınık halde bulunur. & 1 \\
\hline & 3 & $\begin{array}{l}\text { Çözünme olayında } \mathrm{NaCl} \text {, iyonlarına ayrılmaz sadece çözünür. Etrafında su } \\
\text { molekülleri olur.* }\end{array}$ & 6 \\
\hline & 4 & Bir maddenin çözünürlüğü, çözücü veya çözünen maddelerin miktarına bağlıdır.* & 20 \\
\hline Çӧzünürlüğe & 5 & Karıştırma ve ufalama hem çözünürlüğü hem de çözünme hızını arttırır. & 30 \\
\hline etki eden & 6 & Sıcaklık gazların çözünürlüğünü arttırır. & 36 \\
\hline \multirow{7}{*}{ faktörler } & 7 & Sıcaklık arttıkça çözünürlüğü artan madde ekzotermiktir. & 4 \\
\hline & 8 & Gazların çözünürlüğü yüksek sıcaklık ve düşük basınçta maksimum noktaya ulaşır. & 3 \\
\hline & 9 & $\begin{array}{l}\text { Katı ve siviların çözünürlüğ̈̈ sıcaklıktan etkilenmez. Sadece gazlar sıcaktan doğru } \\
\text { orantılı olarak etkilenir.* }\end{array}$ & 2 \\
\hline & 10 & Çözeltiyi soğutmak çözünürlüğü hiçbir şekilde arttırmaz.** & 1 \\
\hline & 11 & Yükseklere çıkıldıkça basınç artar bu yüzden $\mathrm{O}_{2}$ gazının sudaki çözünürlüğü artar. & 10 \\
\hline & 12 & Katıların çözünürlüğ̈̈ basınç arttıkça artar. & 3 \\
\hline & 13 & $\begin{array}{l}\text { Buhar basıncı ile gazların çözünürlüğü doğru orantılıdır. Ankara da buhar basınc1 } \\
\text { azdır, çözünürlük daha fazladır.* }\end{array}$ & 2 \\
\hline
\end{tabular}

\section{Gaz Yasaları Konusundaki Alternatif Kavramlar}

KİKAT'in gaz yasaları ile ilgili 20.-25. sorularına öğrencilerin verdikleri cevaplardan tespit edilen alternatif kavramlar Tablo 4'te sunulmaktadır.

Tablo 4 "Gaz Yasaları” Konusunda Tespit Edilen Alternatif Kavramlar

\begin{tabular}{|c|c|c|c|}
\hline $\begin{array}{l}\text { Tanımlayıcı } \\
\text { Kategoriler }\end{array}$ & $\mathbf{N}$ & Öğrencilerin Alternatif Kavramları & f \\
\hline $\begin{array}{l}\text { Sicaklık-gaz } \\
\text { basincl }\end{array}$ & 1 & $\begin{array}{l}\text { İçinde gaz bulunan pistonlu bir enjektör sırayla buzlu suya ve sicak suya } \\
\text { daldırıldı̆ıında basıncı önce azalır sonra artar. (Pistonlu kaplarda gaz basınc1 } \\
\text { sıcaklığa bağlı olarak artıp azalır).* }\end{array}$ & 43 \\
\hline \multirow{2}{*}{$\begin{array}{l}\text { Hacim-gaz } \\
\text { basincl }\end{array}$} & 2 & $\begin{array}{l}\text { Bir enjektördeki gazın basıncı artarsa, enjektörün içine yerleştirilmiş lastik } \\
\text { balondaki gazın basıncı azalır. }\end{array}$ & 7 \\
\hline & 3 & Gazlarda hacim arttıkça basınçta artar. & 6 \\
\hline \multirow{2}{*}{$\begin{array}{l}\text { Sicaklık-gaz } \\
\text { hacmi } \\
\text { Mol sayısl-gaz } \\
\text { basincl }\end{array}$} & 4 & Gazlarda hacim ile sicaklık ters orantılıdır. & 3 \\
\hline & 5 & Kapalı bir kaba sıvı doldurdukça kabın üzerindeki gazın basıncı azalır.* & 3 \\
\hline \multirow{5}{*}{$\begin{array}{l}\text { Sicaklık-gaz } \\
\text { molekülü ilişkisi }\end{array}$} & 6 & Sıcaklık arttıkça hacim artığı için gaz moleküllerinin hacmi genişler. & 5 \\
\hline & 7 & Buzlu su içine daldırılmış bir enjektör içindeki gaz molekülleri büzüşür.* & 2 \\
\hline & 8 & $\begin{array}{l}\text { Ağzı kapalı kaplarda bulunan gaz molekülleri isıtıldıkça moleküller kabın } \\
\text { yukarısında toplanırlar. }\end{array}$ & 20 \\
\hline & 9 & Gaz molekülleri soğutuldukça enerjileri tükenir, gaz hareketsiz durur. & 8 \\
\hline & 10 & $\begin{array}{l}\text { Bir kapta bulunan gaz molekülleri 1sitıldığında yoğunluğu azalacağı için kabın } \\
\text { yukarısına çıkarlar. }\end{array}$ & 1 \\
\hline
\end{tabular}


11 Sıcaklığın artması ile gaz molekülleri arasında kinetik enerji azalır.* 1

12 Hava sıcaklığı azaldıkça bir toptaki gaz moleküllerinin boyutu küçüldüğü için 1 topun hacmi azalır.

Tablo 4 incelendiğinde, gaz yasaları konusunda öğrencilerin 12 farklı alternatif kavrama sahip olduğu gözlenmektedir. Bu alternatif kavramlar "sıcaklık-basınç", "hacim-basınç", "sıcaklık-hacim”, “mol sayısı-basınç” ve "sıcaklık-gaz molekülü ilişkisi”" kategorilerinde yer almaktadır. Öğrencilerde en fazla sıklıkta 1 numaralı alternatif kavramın, en az sıklıkta ise 10, 11 ve 12 numaralı alternatif kavramların olduğu belirlenmiştir.

\section{Reaksiyon Hızına Etki Eden Faktörler Konusundaki Alternatif Kavramlar}

KİKAT'in reaksiyon hızına etki eden faktörler ile ilgili 26.-32. sorularına öğrencilerin verdikleri cevaplardan tespit edilen alternatif kavramlar Tablo 5 'te sunulmaktadır.

Tablo 5 "Reaksiyon Hızına Etki Eden Faktörler” Konusunda Tespit Edilen Alternatif Kavramlar

\begin{tabular}{|c|c|c|c|}
\hline $\begin{array}{l}\text { Tanımlayıcı } \\
\text { Kategoriler }\end{array}$ & $\mathbf{N}$ & Öğrencilerin Alternatif Kavramları & $\mathbf{f}$ \\
\hline Reaksiyona & 1 & Reaksiyona giren maddelerin molekül büyüklüğü reaksiyon hızını yavaşlatır.* & 10 \\
\hline $\begin{array}{l}\text { giren } \\
\text { maddelerin }\end{array}$ & 2 & $\begin{array}{l}\text { Reaksiyona giren maddenin kütlesi ne kadar az ise reaksiyon o kadar hizlı } \\
\text { gerceklesir. }\end{array}$ & 10 \\
\hline $\begin{array}{l}\text { özellikleri- } \\
\text { tepkime hızı }\end{array}$ & 3 & $\begin{array}{l}\text { Reaksiyon hızına maddenin katı, sıvı ya da gaz olması etki eder. Katı maddeler } \\
\text { daha geç reaksiyona girer. }\end{array}$ & 5 \\
\hline Sicaklık- & 4 & Şeker, soğuk suya göre sıcak suda daha hızlı reaksiyona girer. & 5 \\
\hline \multirow[t]{3}{*}{ tepkime hızı } & 5 & Ekzotermik reaksiyonlarda sıcaklık artışı reaksiyonu yavaşlatır. & 40 \\
\hline & 6 & Sıcaklık tanecikler arası çekim kuvvetini azaltacağı için reaksiyonu hızlandırır.* & 2 \\
\hline & 7 & Sıcaklık moleküller arasındaki bağı zayıflattığ 1 için tepkimeyi hızlandırır.* & 4 \\
\hline $\begin{array}{l}\text { Derişim, } \\
\text { basıç-tepkime }\end{array}$ & 8 & $\begin{array}{l}\text { Reaksiyonların hızı girenlerin derişiminden bağımsızdır, ürünlerin derişimiyle } \\
\text { ilişkilidir.* }\end{array}$ & 13 \\
\hline \multirow[t]{2}{*}{ hizl } & 9 & Derişim arttıkça reaksiyon hızı azalır. & 16 \\
\hline & 10 & Basıncın azalması reaksiyon hızını arttırır, yemeğin daha hızlı pişmesini sağlar. & 4 \\
\hline $\begin{array}{l}\text { Karıştırma, } \\
\text { katalizör- }\end{array}$ & 11 & $\begin{array}{l}\text { Karıştırmak reaksiyon hızını azaltır. Yemeği karıştırmak yemeğin soğumasına } \\
\text { neden olduğu için yemek yavaş pişer. }\end{array}$ & 4 \\
\hline \multirow[t]{4}{*}{ tepkime hızı } & 12 & Katalizörler reaksiyon hızını yavaşlatırlar. & 3 \\
\hline & 13 & Katalizörler maddelerin çarpışma hızını arttırdığ & 3 \\
\hline & 14 & Katalizör reaksiyona renk veren maddedir. & 1 \\
\hline & 15 & Katalizörlerin reaksiyonun aktivasyon enerjisine etkisi yoktur. & 1 \\
\hline
\end{tabular}

Tablo 5 incelendiğinde, reaksiyon hızına etki eden faktörler konusunda öğrencilerin 15 farklı alternatif kavrama sahip olduğu gözlenmektedir. Bu alternatif kavramlar "reaksiyona giren maddelerin özellikleri-tepkime hızı”, “sıcaklık-tepkime hızı”, “derişim, basınç-tepkime hızı" ve "karıştırma, katalizör- tepkime hızı" kategorilerinde yer almaktadır. Öğrencilerde en fazla sıklıkta 5 numaralı alternatif kavramın, en az s1klıkta ise 14 ve 15 numaralı alternatif kavramların olduğu belirlenmiştir.

\section{Elektrokimyasal Piller Konusundaki Alternatif Kavramlar}


KİKAT'in elektrokimyasal piller ile ilgili 33.-38. sorularına öğrencilerin verdikleri cevaplardan tespit edilen alternatif kavramlar Tablo 6'da sunulmaktadır.

Tablo 6 "Elektrokimyasal Piller" Konusunda Tespit Edilen Alternatif Kavramlar

\begin{tabular}{llll}
\hline $\begin{array}{l}\text { Tanımlayıcı } \\
\text { Kategoriler }\end{array}$ & N & Öğrencilerin Alternatif Kavramları & f \\
\hline Anot-katot & 1 & $\begin{array}{l}\text { Yükseltgenmenin olduğu anot elektrotta zamanla kütle artışı görülürken, } \\
\text { indirgenmenin olduğu katot elektrotta zamanla aşınma görülür. }\end{array}$ & 3 \\
& 2 & $\begin{array}{l}\text { Anotta indirgenme, katotta yükseltgenme olur. } \\
\text { Galvanik hücrede anot ve katotun yerlerini belirleyememe. }\end{array}$ & 7 \\
& 3 & Aktifliği büyük olan elektron alır katottur, aktifliği küçük olan anottur. & 4 \\
& 4 & Katot elektrot voltmetrenin - kutbuna, anot ise + kutbuna bağlanır. Anot,+ & 4 \\
Elektronların & 6 & Elektronlar diş devrede katottan anota doğru gider. & 10 \\
yönü & 7 & Elektronlar +'dan -'ye doğru hareket ederler. & 1 \\
Tuz köprüsü & 8 & Tuz köprüsü anot ve katot arasında çözelti içinden elektronların geçişini sağlar. & 23 \\
ve işlevi & 9 & Tuz köprüsü katottan anot kabına iyon geçmesini sağlar. & 9 \\
& 10 & Tuz köprüsü üzerinden, anottan katota iyon geçişi olur. & 3 \\
& 11 & Tuz köprüsünden katota - yüklü iyonlar, anota + yüklü iyonlar gelir. & 5 \\
& 12 & Anot kabında + yüklü iyon sayısı zamanla azalır. & 6 \\
\hline
\end{tabular}

Tablo 6 incelendiğinde, elektrokimyasal piller konusunda öğrencilerin 12 farkl1 alternatif kavrama sahip olduğu gözlenmektedir. Bu alternatif kavramlar "anot-katot", “elektronların yönü” ve “tuz köprüsü ve işlevi” kategorilerinde yer almaktadır. Öğrencilerde en fazla sıklıkta 3 ve 8 numaralı alternatif kavramların, en az sıklıkta ise 7 numaralı alternatif kavramın olduğu belirlenmiştir.

\section{Sonuç ve Tartışma}

Fen bilgisi öğretmen adaylarının bu araştırma kapsamında ele alınan kimya konularını hem lise hem de üniversite 1 ve 2. sınıflarda öğrenmiş olmalarına rağmen onların halen daha aynı konularda çeşitli alternatif kavramlara sahip oldukları tespit edilmiştir.

\section{“Buharlaşma ve Kaynama” Kavramlarına Yönelik Sonuç ve Tartışma}

Araştırma kapsamında öğrencilerde buharlaşma ve kaynama kavramlarına yönelik tespit edilen alternatif kavramlardan bazıları; "sıcaklık artışı olmazsa buharlaşma olmaz (1)" ve "bir buharlaşma işleminin gerçekleşmesi için sıvının kaynayarak moleküllerinin birbirinden ayrılması gerekir (2).” ifadeleridir (Tablo 1). Öğrencilerde bu alternatif kavramlara rastlanılmasının sebebi, onların sıvı miktarındaki azalmayı en somut görebildikleri anın sıcaklık artışının olduğu zamanlar olması olabilir. Bir başka neden ise buharlaşma olayının 
sadece sıvının üzerinde buhar gördükleri takdirde gerçekleştiğini ve günlük deneyimlerinden bu buharların sıcaklıkla arttığını bilmeleri ya da sıvı kaynarken bunu görmeleri etkili olmuş olabilir (Coştu vd., 2007; Karsl1, 2011). Bunun yanı sıra tespit edilen diğer alternatif kavramlar "su buharlaşırken fiziksel değişime, etil alkol ise kimyasal değişime uğrayarak bileşenlerine ayrılır (3).” şeklindedir (Tablo 1). Öğrencilerin suyun buharlaşmasını fiziksel, etil alkolün buharlaşmasını ise kimyasal değişim olarak düşünmelerinde, onların fiziksel ve kimyasal değişim kavramlarıyla ilgili bilgilerinin eksik oluşu etkili olmuş olabilir (Bar ve Travis, 1991; Coştu ve Ayas, 2005). Bir başka neden ise öğretmenlerin buharlaşma kavramını anlatırken hep su örneğini kullanmaları öğrencilerce diğer sıvılar için durumun farklıymış gibi algılanmasına neden olmuş olabilir. Birçok çalışma sonuçlarında da öğrencilerin suyun buharlaşması sırasında hidrojen ve oksijen gazları oluştuğu için buharlaşma olayını kimyasal değişim olarak düşündükleri ortaya koyulmuştur (Örneğin; Chang, 1999; Çalık, 2005; Karslı, 2011). Öğrencilerin buharlaşmanın sıvının tümünde, kaynamanın ise sadece yüzeyde olduğunu düşünmeleri, buharlaşma ve kaynama olaylarının sıvının hangi bölgelerinde gerçekleştiğinin gözle görülemeyen durumlarla ilgili olmasına dayandırılabilir (Canpolat vd., 2006; Coştu ve Ayas, 2005).

Öğrencilerde Tablo 1'de "buharlaşma ve kaynama" kategorisinde (5)-(9) numaralı alternatif kavramların oluşması, öğrencilerin buharlaşma olayını kimyasal değişim olarak düşünmelerinden (Chang, 1999; Çalık, 2005) ya da buharlaşma olayını fiziksel değişim olarak düşünseler bile çıkan gazın sıvının kendi molekülü olması gerektiğini göz ardı etmelerinden kaynaklanabilir. Ya da sıcaklığın buharlaşma ve kaynamada bağların kopmasını sağlayıcı bir etkiye sahip olduğunu (Osborne ve Cosgrove, 1983; Tytler, 2000) düşünmeleri neden olarak gösterilebilir. Öğrencilerin kaynama esnasında verilen 1sı ile birlikte kinetik enerjinin artması yönündeki alternatif kavramları, onların bir maddeye 1sı verildiğinde her zaman sıcaklığın dolayısıyla kinetik enerjinin arttırdığını düşünmelerinden kaynaklanabilir. Dolayısıyla öğrenciler hal değiştirirken de sıcaklığın artmasını kinetik enerjinin artmasıyla ilişkilendirmiş olabilirler. Bu sonuç Hwang ve Hwang (1990)'ın öğrenciler sıvı kaynarken enerji dengesini anlamazlar, onlar kaynayan sıvıyı 1sıttıkça sıcaklığının artığına inanırlar şeklindeki sonucuyla paralellik göstermektedir.

Öğrencilerde sıvılarda kaynama noktası'nı (KN) etkileyen faktörlerle ilgili KN'yi kaynatılan yerden bağımsız olarak düşünmelerinde (Tablo 1, 10 numaralı alternatif kavram), öğrencilere bu konu anlatılırken sürekli su her zaman $100{ }^{\circ} \mathrm{C}$ 'de alkol $78{ }^{\circ} \mathrm{C}$ 'de kaynar şeklinde uyarılar verilmesi sebep olmuş olabilir (Coştu vd., 2003; Coştu vd., 2007; Pınarbaş1 ve Canpolat, 2003). Buna ek olarak öğrencilerin dış basınç ile $\mathrm{KN}$ arasındaki ilişkiyi 
açıklamada sorun yaşamalarına, dış basıncın iller bazında (Ağrı, Ankara ve Giresun) nasıl değiştiğini kestirememeleri sebep gösterilebilir. Öğrencilerde, "1sı kaynağının güçlü olması KN'yi arttırır (13).” ve “sıvının saflığı KN'yi etkilemez (14).” şeklinde alternatif kavramların oluşmasında öğrencilerin kaynama süresi ile KN kavramlarını birlikte düşünmeleri etkili olmuş olabilir. Çünkü öğrenciler bir sıvının KN'si düşük ise erken kaynar, yüksek ise geç kaynar şeklinde düşünerek, sıvıların içinde katı bir maddenin çözünüp çözünmediğini ve 1sıtıcı şiddetlerini göz ardı etmiş olabilirler (Coştu vd., 2007; Hwang ve Hwang, 1990; Paik vd., 2004; Pınarbaşı ve Canpolat, 2003; Uzuntiryaki ve Geban, 2005; Valanides, 2000; Varelas vd., 2006). Literatürde KN'ye etki eden faktörlerle ilgili "sıvının ilk sıcaklığı o sıvının KN'sini etkiler (12).” şeklinde bir alternatif kavrama rastlanılmamıştır. Böyle bir alternatif kavramın belirlenmiş olması her ne kadar istenmeyen bir durum olarak düşünülse de literatüre yeni bir katkı getirdiği söylenebilir. Bu alternatif kavramın oluşma sebebi, öğrencilerin sıvıların ilk sıcaklığı ne kadar yüksek ise kaynamasının da o kadar kısa sürede meydana geleceğini düşünerek, kaynama süresi ile KN'yi birlikte düşünmelerinin bir sonucu olabilir.

Öğrencilerde yukarıda belirtilen alternatif kavramların yanı sıra, buhar basıncı ile ilgili Tablo 1'de verilen (21), (22) ve (23) numaralı ifadelerde sunulan alternatif kavramlar da tespit edilmiştir. Buhar basıncı ile ilgili bu alternatif kavramların oluşmasında ise öğrencilerin KN ile buhar basıncı kavramlarını tam olarak ilişkilendirememeleri ve buhar basıncının hangi hallerde değiştiğini bilmemeleri etkili olmuş olabilir (Canpolat vd., 2006). Ya da buhar basıncı ile dış basınç kavramlarını birbirinin yerine kullanmış olabilirler. Öğrenciler kendi zihinlerinde oluşturdukları alternatif kavramları doğrudan veya dolaylı olarak diğer kavramlarla ilişkilendirebilmekte ve kavramlar arasında ilişkilendirme yaparken başka alternatif kavramları yapılandırabilmektedirler. $\mathrm{Bu}$ durum onların üst düzey öğrenmelerini olumsuz etkilemektedir (Ayas vd., 2010; Canpolat vd., 2004; Çalık ve Ayas, 2005a; Niaz vd.,2002).

\section{“Asit-Baz Nötrleşme Reaksiyonları” Konusundaki Kavramlara Yönelik Sonuç ve Tartışma}

Araştırma kapsamındaki öğrencilerde "asit-baz nötrleşme reaksiyonları" konusunda "sadece kuvvetli asitle kuvvetli baz tepkimeye girdiğinde ya da ikisi de zayıf olduğunda nötrleşme tepkimesi gerçekleşir (1)" şeklinde bir alternatif kavrama rastlanılmasında, onların nötrleşme kelimesini birbirinin etkisini nötrleme olarak düşünerek ikisinin de kuvvetli ya da ikisinin de zayıf olması durumunda bunun gerçekleşeceğini düşünmeleri etkili olmuş olabilir (Demircioğlu vd., 2005; Karsl1, 2011; Pınarbaş1, 2007; Zoller, 1990). Ya da öğrenciler 
nötrleşme olayını çözeltinin nötral olması anlamına geldiği şeklinde yorumlamış olabilirler. $\mathrm{Bu}$ durum, öğrencilerin kimya kavramlarını açıklarken kullandıkları terimlerin, aslında farklı bir anlama sahip olabileceğinin bir göstergesi şeklinde değerlendirilebilir. Bununla birlikte, bazı öğrencilerin nötrleşme tepkimesi sonucu oluşan çözeltinin özelliği ile ilgili sahip oldukları alternatif kavramları; "nötrleşme tepkimesi sonucu her zaman bir nötr tuz ve su oluşur ve pH her zaman 7'dir (2).”, "renk dönüşümünün olduğu nokta, nötrleşmenin olduğu, pH'nın her zaman 7 ve ortamın nötr olduğu yerdir (3).” şeklindedir (Tablo 2). Öğrencilerde bu alternatif kavramların oluşmasında onların oluşan çözeltinin nötral olması $(\mathrm{pH}=7)$ ile nötrleşme tepkimesi kavramlarını eş değer düşünmeleri etkili olmuş olabilir. $\mathrm{Bu}$ durum fen kavramlarının öğretiminde, gündelik hayattaki dilin kullanımının öğrencilerde alternatif kavramlara neden olmasının bir sonucu olabilir (Boz, 2009). Buna ek olarak gerek ders kitaplarında gerekse deneylerde nötrleşme tepkimesine verilen asit-baz örneklerinin, genelde eşit derişimlerde kuvvetli asit ve baz çiftlerinden oluşması ve ortamın pH'sının 7 olarak örnek verilmesi etkili olmuş olabilir. Ya da, bu bilgilerin ezberci bir yaklaşımla tanımlanması neden gösterilebilir (Hand ve Treagust, 1988; Ross ve Munby, 1991). Öğrencilerde tam nötrleşme ile ilgili alternatif kavramların oluşmasında onların tam nötrleşmeyi, sadece asit ve bazın kuvvetinin eşit olması durumunda gerçekleşebileceğini düşünmeleri, tepkime tamamlandığ an tam nötrleşme gerçekleşmiş olur düşüncesini göz ardı etmeleri etkili olmuş olabilir (Demircioğlu, Özmen ve Ayas, 2004). Bu araştırmada öğrencilerin, “üründe tuz oluşmuş bütün tepkimeler nötrleşme tepkimesidir (6)." şeklinde literatürde rastlanmayan bir alternatif kavrama sahip oldukları tespit edilmiştir. Böyle bir alternatif kavramın belirlenmesi her ne kadar istenmeyen bir durum olarak düşünülse de literatüre yeni bir katkı getirdiği söylenebilir. Öğrencilerin üründe tuz oluşan bütün reaksiyonları nötrleşme reaksiyonu olarak algılamalarında, öğretmenlerce ya da ders kitaplarında nötrleşme sonucu üründe her zaman tuz ve su oluşur şeklinde vurgulama yapılması, onların bütün tuz oluşan reaksiyonları nötrleşme olarak algılamalarına neden olmuş olabilir. Öğrencilerde "asit ve baz titrasyonunda renk değişimi gerçekleştiği için bu fiziksel bir olaydır (7).” şeklinde bir alternatif kavramın oluşmasında ise renk dönüşümlerinin genel olarak fiziksel değişim sonucu oluştuğunu biliyor olmaları neden gösterilebilir. Ayrıca bazı öğrencilerde, "asit ve baz karıştırıldığında kimyasal bir tepkime değil nötrleşme tepkimesi gerçekleşir (8).” şeklinde bir alternatif kavramın olması da bu durumu desteklemektedir (Demerouti vd., 2004).

“Çözünme ve Çözünürlüğe Etki Eden Faktörler” Konusundaki Kavramlara Yönelik Sonuç ve Tartışma 
Öğrencilerde "çözünme" kavramı ile ilgili belirlenen alternatif kavramlar; "tuz su içerisinde çözünür ve yeni bir bileşik oluşur (1)", "NaCl molekülleri su içinde çözünürken rastgele dağınık halde bulunur (2)" ve “çözünme olayında $\mathrm{NaCl}$, iyonlarına ayrılmaz sadece çözünür, etrafında su molekülleri olur (3).” şeklinde sıralanabilir. Daha önceki yıllarda çözünme kavramını öğrenmelerine rağmen öğrencilerde bu alternatif kavramların oluşmasına, onlara sözel olarak anlatılan ve hayal etmeleri istenen soyut bir olgunun, zihinde canlandırılmasına imkan tanıyacak materyallerin yeterince kullanılmaması neden gösterilebilir (Akgün, 2009; Çalık ve Ayas, 2005b; Kabapınar vd., 2004; Kalın ve Arıkıl, 2010). Bir başka neden de, öğrencilere ilköğretimden itibaren çözünme olayının sadece homojen dağılma olarak anlatılması ve molekül yapılarının nasıl göründüğüne vurgu yapılmaması da olabilir (Çalık ve Ayas, 2005a; 2005b; Uzuntiryaki, 1998). Bununla birlikte çözünürlüğe etki eden faktörlerle ilgili belirlenen alternatif kavramlar; "Bir maddenin çözünürlüğü, çözücü veya çözünen maddelerin miktarına bağlıdır (4).” ve "Karıştırma ve ufalama hem çözünürlüğü hem de çözünme hızını arttırır (5).” şeklindedir. Öğrencilerin madde miktarının çözünürlüğü etkilediğini düşünmelerinde, çözücüye ne kadar çözünen madde eklenirse o derecede çözünmenin artacağını düşünmeleri etkili olmuş olabilir. Fakat burada, her çözücünün belirli koşullarda çözebileceği bir miktar olduğunun ve bu miktar aşıldığında artık çözünmenin olmayacağı gerçeğinin göz ardı edildiği dikkat çekmektedir. Karıştırma ve ufalama işlemlerinin çözünürlüğü arttırdığını düşünmelerinde ise günlük hayatlarında katı-sıvı çözeltisi karıştırıldığı zaman daha fazla miktarda katının çözünebildiğini görmeleri etkili olmuş olabilir (Blanco ve Prieto, 1997; Çalık ve Ayas, 2005a; Uzuntiryaki, 1998; Pınarbaşı, 2002). Bazı öğrencilerin ise sıcaklığın çözünürlüğe etkisi ile ilgili olarak; (6), (7), (8), (9) ve (10) numaralı alternatif kavramlara sahip olduğu belirlenmiştir (Tablo 3). Sıcaklığın çözünürlüğe etkisi ile ilgili bu alternatif kavramların oluşmasında, öğrencilerin endotermik ve ekzotermik çözünen maddelerde çözünürlüğün nasıl değiştiğini bilmemeleri etkili olmuş olabilir (Tezcan ve Bilgin, 2004). Ya da, hem günlük hayatta hem de yaptıkları deneyler sırasında genelde dipte kalan maddelerin çözünmelerinin sıcaklıkla arttığını gözlemlemeleri etkili olmuş olabilir. Bu yüzden, çözeltiyi soğutmak çözünürlüğü hiçbir şekilde arttırmaz düşüncesi soğuk ortamda çözünmenin meydana gelmeyeceği inancından, öğrencilerin olayı zihinlerinde canlandıramamalarından kaynaklanabilir (Blanco ve Prieto, 1997). Çözünürlüğe basıncın etkisi ile ilgili olarak ise bazı öğrencilerin; "yükseklere çıkıldıkça basınç artar bu yüzden sudaki çözünürlük artar (11).”, "katıların çözünürlüğü basınç arttıkça artar (12)” ve "buhar basıncı ile gazların çözünürlüğü doğru orantılıdır. Ankara 
da buhar basıncı azdır, çözünürlük daha fazladır (13).” gibi alternatif kavramlara sahip olduğu görülmektedir (Tablo 3). Öğrencilerde bu alternatif kavramların oluşmasında basıncın deniz seviyesine uzak ya da yakın yerlerde nasıl değiştiğinin karıştırılması etkili olmuş olabilir. Buna ek olarak, öğrencilerin dış basınç ve buhar basıncı kavramlarını bir birinin yerine kullandıkları görülmektedir. Bu durum, çözünürlükle ilgili farklı kavramları tanımlamak için kullanılan dil ile öğrencilerin kimya kavramlarını açıklarken kullandıkları terimlerin, aslında farklı bir anlama sahip olabileceğinin (Ebenezer ve Gaskell, 1995) ve çözünürlük kavramında öğrencilerin bu kavram ile kesin manada çok az ilişkili olan kavramları birbirine karıştırmalarının bir sonucu olarak düşünülebilir (Prieto vd., 1989). Ayrıca katıların çözünürlüğunün de basınçtan etkilendiğini belirtmelerinde, fizik konusunda katı basıncı kavramından çağrışım yaparak bu cevabı vermeleri etkili olmuş olabilir.

\section{“Gaz Yasalarl” Konusundaki Kavramlara Yönelik Sonuç ve Tartışma}

Gaz yasaları konusunda "içinde bir miktar gaz bulunan pistonlu bir enjektör sırayla buzlu suya ve sıcak suya daldırıldığında basıncı önce azalır sonra artar (1)" şeklinde belirlenen alternatif kavramın oluşmasında öğrencilerin $\mathrm{PV}=\mathrm{nRT}$ bağıntısını ezberledikleri için bu bağıntıyı tam olarak kullanamamaları etkili olmuş olabilir (Bak vd., 2008; Karslı, 2011; Lin vd., 2000). Ya da öğrencilerin önceki aldıkları öğretimlerinde pistonlu kapların özelliği üzerine vurgu yapılmadığı için pistonlu kaplarda (basıncın sabit olduğu kaplarda) istisnai durumun olduğunu göz ardı etmeleri etkili olmuş olabilir (Birinci Konur ve Ayas, 2010; Karsl1, 2011). Bu durumu, Tablo 4'te öğrencilerin "bir enjektördeki gazın basınc1 artarsa, enjektörün içine yerleştirilmiş lastik balondaki gazın basıncı azalır (2)." şeklindeki alternatif kavramdan da anlamak mümkündür. Öğrenciler, enjektörün içine yerleştirilmiş lastik balonunda bir sürtünmesiz piston gibi davrandığını ve lastik balonlarda da içteki basıncın dış basınca eşit olması gerektiğini göz ardı etmiş olabilirler. Öğrencilerde, gazlarda basınç-hacim ilişkisi ve sıcaklık-hacim ilişkisi konularında alternatif kavramların varlığı tespit edilmiştir. Bu alternatif kavramların oluşmasına, öğrencilerin $\mathrm{PV}=\mathrm{nRT}$ formülünün anlamını tam olarak bilmemeleri ve bu bağıntıyı uygunsuz kullanmaları neden gösterilebilir (Bak vd., 2008; Kautz vd., 2005; Karslı, 2011; Lin vd., 2000). Bununla birlikte, sicaklık-gaz molekülü ilişkisi kategorisi altında yer alan bir kaptaki gaz moleküllerinin sıcaklık değiştikçe şekli, konumu ve hareketi ile ilgili öğrencilerin alternatif kavramlara sahip olmalarına, gazların özellikleriyle ilgili ön öğrenmelerinin yetersiz ve yüzeysel olması neden gösterilebilir veya gazların görünmezliğinin öğrencilerin gaz kavramını oluşturmalarına engel olması (Stavy, 1988), başka bir deyişle gaz davranışlarını görsel olarak algılayamamaları da neden olabilir. 
Bütün bu nedenler öğrencilerin gazların davranışlarını açıklamada kullanılan kinetik teoriyi kavramsal düzeyde algılayamamalarının bir sonucudur.

\section{"Reaksiyon Hızına Etki Eden Faktörler" Konusundaki Kavramlara Yönelik Sonuç ve} Tartışma

Öğrencilerde, "reaksiyon hızına etki eden faktörler" konusunda, reaksiyona giren maddelerin özellikleri-tepkime hızı kategorisinde yer alan alternatif kavramların var olması, öğrencilerin reaksiyon hızına madde cinsini açıklarken, madde cinsi-reaktantların doğası arasında doğrudan bir ilişki kuramamaları neden gösterilebilir. Buna ek olarak öğrencilerin kimyasal değişme boyunca gerçekleşecek bağ kırılma ve oluşmalarının hızını, bu bağların ve bunların oluşturduğu moleküllerin yapısına göre değişebileceğini göz ardı etmeleri etkili olmuş olabilir (Çakmakçı, 2005; Karslı, 2011; Nakiboğlu vd., 2002; Taştan vd., 2010). Öğrencilerde "sıcaklık-tepkime hızı arasındaki ilişki” ile ilgili bazı alternatif kavramlar mevcuttur (Tablo 5). Bazı öğrenciler şekerin çözünmesini kimyasal reaksiyon olarak düşünmüş ve entalpi ile reaksiyon hızı arasındaki ilişkiyi sebebiyle birlikte açıklayamamışlardır. Öğrencilerin sıcaklığın reaksiyon hızını, tepkime endotermik ise arttırıcı yönde ekzotermik ise azaltıcı yönde etki ettiğini belirtmelerinde, reaksiyon hızı konusunu kimyasal denge kanunlarıyla karıştırmaları (Hackling ve Garnett, 1985) ya da öğrencilerin mikroskobik düzeydeki olayları zihinlerinde canlandıramaması ve kavramı net olarak oluşturamamaları etkili olmuş olabilir (Kolomuç, 2009; Nakiboğlu vd., 2002). "Derişim, basınç-tepkime hızı" arasındaki ilişki için belirlenen alternatif kavramların oluşmasında, öğrencilerin reaksiyon hızını girenlerin derişiminden bağımsız olarak düşünmeleri, hız kavramı anlatılırken sadece matematiksel formüllerin gösterilmesi sonucunda öğrencilerin formüldeki kavramları birbirine karıştırmaları ya da hız denklemini, kimyasal denge formülüyle karıştırmaları etkili olmuş olabilir (Çakmakçı, 2005; Hackling ve Garnett, 1985). Ayrıca bu durum, öğrencilerin hız yasası eşitliği ile etkin çarpışma kavramlarını zihinlerinde oluşturamamalarının bir sonucu olarak da düşünülebilir (Çakmakçı, 2005; Çakmakçı vd., 2006; Nakiboğlu vd., 2002). Bununla birlikte, öğrencilerde "karıştırma-tepkime hızı ve katalizör-tepkime hızı” arasındaki ilişkiler için belirlenen alternatif kavramların oluşmasında, onların katalizörün etkisini aktivasyon enerjisi açısından ele almamaları ve katalizörün mikroskobik boyutta bir reaksiyondaki işlevinin tam olarak ne olduğunu bilmemeleri etkili olmuş olabilir (Kolomuç, 2009; Nakiboğlu vd., 2002).

\section{“Elektrokimyasal Piller” Konusundaki Kavramlara Yönelik Sonuç ve Tartışma}


Öğrencilerde “elektrokimyasal piller” konusundaki kavramlara yönelik Tablo 6'da (1) ve (2) numarada tespit edilen alternatif kavramlara rastlanılmasında, onların dış devrede elektron yönünü ve hangi elektrodun anot hangisinin katot olduğunu belirleyememeleri neden gösterilebilir (Garnett ve Treagust,1992b; Karsl1, 2011; Karslı ve Çalık, 2012; Sanger ve Greenbowe, 1997, 1999; Yılmaz vd., 2002). Buna ek olarak, öğrencilere bu konular ögretilirken olayların deney yolu ile gösterilmeksizin sadece sözel olarak söylenilip geçilmesi ve öğrencilerin bilgileri ders kitaplarından ezberlemek zorunda kaldıkları için hafizalarının onları yanıltmış olması da düşünülebilir (Karsl1, 2011; Karslı ve Çalık, 2012; Yılmaz vd., 2002). Öğrencilerde anot ve katot kavramlarına yönelik olarak belirlenen ve Tablo 6'da sunulan (3), (4) ve (5) numaralı alternatif kavramların oluşmasında ise onların anotun ve katotun yerlerini belirlerken anotun sağ, katotun sol tarafta olduğunu düşünmeleri (Garnett ve Treagust, 1992b; Sanger ve Greenbowe, 1997a, 1999) ve anot ve katotu metallerin aktiflikleri ile ilişkilendirememeleri (Karslı, 2011; Karslı ve Çalık, 2012; Yılmaz vd., 2002) neden gösterilebilir. Buna ek olarak, elektrokimyasal pil devresi gösterimlerinde ders kitaplarında ve öğretmenlerin konuyu anlatırken ki çizimlerinde genelde sol tarafta anot kabının, sağ tarafta ise katot kabının gösterilmesi etkili olmuş olabilir (Atkins ve Jones, 1998; Ebbing ve Wrighton, 1993). Buna benzer olarak, öğrencilerin çoğu anotun elektron verdiği için + yüklü, katodun elektron aldığı için - yüklü olduğuna inanmaktadırlar. Öğrencilerde bu tür bir alternatif kavrama rastlanılmasında; fizik derslerinde ve fizik ders kitaplarında elektrik konusunda öğrencilere "anot + , katot - dir." şeklinde bilgi verilmesi etkili olmuş olabilir (Fishbane vd., 2003; Karslı, 2011; Karslı ve Çalık, 2012).

Öğrencilerin dış devrede elektronların hareket yönü ile ilgili sahip olduğu alternatif kavramlar ise; “elektronlar dış devrede katottan anota doğru gider." ve "elektronlar +'dan "ye doğru hareket ederler." şeklindedir. Bu alternatif kavramların açığa çıkmasında, öğrencilerin “anotta indirgenme, katotta yükseltgenme olur” şeklinde sahip olduğu alternatif kavramından kaynaklanan başka bir alternatif kavramın oluşması etkili olmuş olabilir (Karslı, 2011; Karslı ve Çalık, 2012; Yılmaz vd., 2002). Bu durum, öğrencilerin kendi zihinlerinde oluşturdukları alternatif kavramlar doğrudan veya dolaylı olarak diğer kavramlarla ilişkili olduğu için, başka alternatif kavramların yapılanmasına neden olabileceği ile açıklanabilir. Çünkü literatürde de alternatif kavramların öğrencilerin daha üst düzey bilgileri öğrenmelerine olumsuz yönde etki ettiği şeklinde ifadelere sıklıkla rastlanılmaktadır (Ayas vd., 2010; Canpolat vd., 2004; Çalık ve Ayas, 2005a; Niaz vd., 2002).

Öğrencilerin tuz köprüsü ve işlevi ile ilgili de alternatif kavramlara sahip olduğu tespit edilmiştir. Öğrencilerde "tuz köprüsü anot ve katot arasında çözelti içinden elektronların 
geçişini sağlar (8)" şeklinde alternatif kavramın oluşmasında, elektronların katota geldikten sonra tuz köprüsünün içinden tekrardan anot kabına geçerek döngüyü bu şekilde tamamladıklarını düşünmeleri etkili olmuş olabilir (Garnett ve Treagust, 1992a, 1992b; Ogude ve Bradley, 1994; Özkaya, 2002; Sanger ve Greenbowe, 1997). “Tuz köprüsü katottan anot kabına iyon geçmesini sağlar (9).” ve "tuz köprüsü üzerinde anottan katota iyon geçişi olur (10)." ş̧eklindeki diğer alternatif kavramların oluşmasında ise, dış devrede elektronların hareketine bağlı olarak iyonlarında tuz köprüsü aracılığı ile bir kaptan diğerine geçtiğini düşünmeleri etkili olmuş olabilir (Karslı, 2011; Karslı ve Çalık, 2012; Ogude ve Bradley, 1994; Sanger ve Greenbowe, 1999; Schmidt vd., 2007). "Tuz köprüsünden katota - yüklü iyonlar, anota + yüklü iyonlar gelir (11).” ve "anot kabında + yüklü iyon sayısı azalır (12).” şeklindeki alternatif kavramların oluşmasında, bazı öğrencilerin katotu - yüklü, anotu ise + yüklü olarak tanımlamalarından kaynaklanmış olabilir (Garnett ve Treagust, 1992b; Sanger ve Greenbowe, 1997, 1999; Schmidt vd., 2007). Çünkü öğrencilerin öğrenme ortamlarına alternatif kavramlarla gelmesi, diğer öğrenmelerini olumsuz yönde etkilemekte ve yanlış düşünceler devamlılık göstermektedir.

$\mathrm{Bu}$ araştırma kapsamında Tablo 1, 2, 3, 4 ve 5'te ilgili konularda * ile işaretlenmiş olan ve literatürde belirtilmeyen alternatif kavramlara rastlanılmıştır. Araştırmada böyle alternatif kavramların belirlenmesi her ne kadar istenmeyen bir durum olsa da alternatif kavramların belirlenmesi, kavramsal değişim çalışmalarının temelini oluşturduğu için literatüre yeni bir katkı sağladığı söylenebilir. Ayrıca, tespit edilen bu alternatif kavramların oluşmasını önlemek için, öğretmenler ve araştırmacılar çalışmalarında bu alternatif kavramları da göz önünde bulundurabilirler.

\section{Öneriler}

Kavram öğretimi ve öğreniminde öğrencilerin alternatif kavramları önemli bir yer tutmaktadır. Bir konudaki alternatif kavram diğer konuların öğrenilmesini olumsuz etkilemektedir. $\mathrm{Bu}$ açıdan, alternatif kavramların erkenden önüne geçilmesinde onların zamanında giderilmesi önemlidir. Öğretmenler, öğrencilerinin ön bilgileri doğrultusunda öğretimlerini planlamalı ve eğer öğrencileri alternatif kavramlara sahipse zamanında önlem almalıdır. Bu açıdan, olumlu yönde kavramsal değişim sağlamak için kullanılacak öğretim materyalleri öğrencilerde çoğunlukla rastlanan ve literatürden tespit edilen alternatif kavramlar dikkate alınarak geliştirilebilir. 
Öğrencilerde olumlu yönde kavramsal değişim gerçekleştirmek için, deney ve anlatım yöntemlerinin (geleneksel öğretim yöntemi) yalnız başına kullanılması yerine deneyin yanı sıra farklı kavramsal değişim yöntemlerinin birlikte kullanılarak geleneksellikten uzaklaşılması, öğretimin zenginleştirilmesi ve bunların birbirini destekleyecek ve eksikliklerini giderecek şekilde birlikte kullanılması sağlanabilir.

Öğrencilere kavram öğretimi yapılırken birçok kavramla ile ilgili bilgiler sözel olarak söylenip geçilmekte ya da defterlerine yazılması istenmektedir. $\mathrm{Bu}$ tür klasikleşmiş uygulamalar yerine, öğrencilere verilecek olan bilgiler söylenmeden önce onların tahmin etmelerine, tahminlerini bizzat deneyerek görmelerine ve sonucu kendilerinin açıklamalarına firsat verecek öğretim aktiviteleri tasarlanabilir.

Soyut ve moleküler düzeyde gerçekleşen kimyasal süreçlerin zihinde daha kolay resmedilmesi, anlamlandırılması ve bu türden soyut kavramlarda oluşan alternatif kavramların giderilmesi için öğretim materyallerinde bilgisayar animasyonlarından ve/veya simülasyonlarından faydalanılabilir. Örneğin, tuz köprüsünün işlevi ile ilgili, sıcaklık ve diğer etkilerle gaz moleküllerinin hareketi ve boyutu ile ilgili, çözünme olayı gibi moleküler düzeyde gerçekleşen olayların zihinde daha doğru bir şekilde resmedilmesi ve canlandırılması için bilgisayar animasyonları kullanılabilir. Bunun yanı sıra, öğretmen ve öğretmen adaylarının konu ile ilgili kendi animasyonlarını geliştirebilme konusunda onlara eğitim verilebilir. Bununla birlikte öğrencilerde bu çalışma kapsamında tespit edilen alternatif kavramların giderilmesi için kavramsal değişim metinleri kullanılarak öğrencilerin kavramları daha doğru ve bilimsel kavramlarla açıklayabilmeleri sağlanabilir. Öğrencilerin gündelik hayatta kullanılan bazı terimlerle fen kavramlarının aslında birbirinden farklı olabileceği konusunda uyarıcı bilgiler verilebilir. Mesela, öğretim sırasında nötrleşme tepkimesinde kullandığımız nötrleşme ile günlük hayatta kullandığımız nötr olmanın anlamlarının farklı olabileceği vurgulanabilir.

NOT: Bu çalışma Karadeniz Teknik Üniversitesi Rektörlüğü Bilimsel Araştırma Projeleri Birimi tarafından BAP 2009.116.002.1 Kodlu Proje kapsamında desteklenmiştir. Yetkililere teşekkür ederiz.

\section{Kaynaklar}


Abdullah, A. \& Scaife, J. (1997). Using interviews to assess children's understanding of science concept. School Science Review, 78(285), 79-84.

Abraham, M.R., Gryzybowski, E.B., Renner, J.W. \& Marek, A.E. (1992). Understanding and misunderstanding of eighth graders of five chemistry concepts found in textbooks. Journal of Research in Science Teaching, 29, 105-120.

Akgün, A. (2009). The relation between science student teachers' misconceptions about solution, dissolution, difusion and their atitudes toward science with their achievement. Education and Science, 34(154), 26-36.

Ayas, A. \& Demirbaş, A. (1997). Turkish secondary students' conception of introductory chemistry concepts. Journal of Chemical Education, 74(5), 518-521.

Ayas, A., Özmen, H. \& Çalık, M. (2010). Students' conceptions of the particulate nature of matter at secondary and tertiary level. International Journal of Science and Mathematics Education, 8(1), 165-184.

Bak, Z., Yaman, F. \& Ayas, A. (2008). Identifying chemistry students' understanding about gases through concept mapping, XXIII CESE Conference, July, Athens.

Bar, V. \& Travis, A.S. (1991). Children's views concerning phase changes. Journal of Research in Science Teaching, 28, 363-382.

Birinci Konur, K. \& Ayas, A. (2010). Sınıf öğretmeni adaylarının gazlarda sıcaklık-hacim-basınç ilişkisini anlama seviyeleri. Türk Fen Eğitimi Dergisi, 7(3), 128-142.

Blanco, A. \& Prieto, T. (1997). Pupils' views on how stirring and temperature affect the dissolution of a solid in a liquid: a cross-age study (12 to 18). International Journal of Science Education, 19(3), 303-315.

Boz, Y. (2009). Turkish prospective chemistry teachers' alternative conceptions about acids and bases. School Science and Mathematics Journal, 109(4), 212-222.

Çakmakçı, G. (2005). A cross-sectional study of the understanding of chemical kinetics among turkish secondary and undergraduate students. $\mathrm{PhD}$ Thesis. The University of Leeds, UK.

Çakmakçı, G., Leach, J. \& Donelly, J. (2006). Students' ideas about reaction rate and its relationship with concentration or pressure. International Journal of Science Education, 28(15), 1795-1815.

Çepni, S. (2007). Araştırma ve proje çalışmalarına giriş (Genişletilmiş 3. Baskı). Trabzon: Celepler Matbaacılık. 
Canpolat, N., Pınarbaşı, T., Bayrakçeken, S. \& Geban, Ö. (2004). Kimyadaki bazı yaygın yanlış kavramalar. Gazi Üniversitesi Eğitim Fakültesi Dergisi, 24(1), 135-146.

Canpolat, N., Pinarbasi, T. \& Sozbilir, M. (2006). Prospective teachers' misconceptions of vaporization and vapor pressure. Journal of Chemical Education, 83(8), 1237-1242.

Chang, J.Y. (1999). Teacher college students' conceptions about evaporation, condensation, and boiling. Science Education, 83, 511-526.

Chou, C. Y. (2002). Science teachers' understanding of concepts in chemistry. Proc. Natl. Sci. Counc. $R O C(D), 12(2), 73-78$.

Coştu, B. \& Ayas, A. (2005). Evaporation in different liquids: secondary students' conceptions. Research in Science and Technological Education, 23(1), 75-97.

Coştu, B., Ayas, A., Niaz, M., Ünal, S. \& Çalık, M. (2007). Facilitating conceptual change in students' understanding of boiling concept. Journal of Science Education Technology, $16,524-536$.

Coştu, B., Karataş, F.Ö. \& Ayas, A. (2003). Kavram öğretiminde çalışma yapraklarının kullanılması. Pamukkale Üniversitesi Eğitim Fakültesi Dergisi, 14(2), 33-48.

Çalık, M. \& Ayas, A. (2005a). 7-10. sınıf öğrencilerinin seçilen çözelti kavramlariyla ilgili anlamalarının farklı karışımlar üzerinde incelenmesi. Türk Eğitim Bilimleri Dergisi, $3(3), 329-347$.

Çalık, M. \& Ayas, A. (2005b). A cross-age study on the understanding of chemical solution and their components. International Education Journal, 6(1), 30-41.

Çalık, M. (2005). A cross-age study of different perspectives in solution chemistry from junior to senior high school. International Journal of Science and Mathematics Education, 3, 671-696.

Çalık, M. (2006). Bütünleştirici öğrenme kuramına göre lise 1 çözeltiler konusunda materyal geliştirilmesi ve uygulanması. Doktora Tezi. Karadeniz Teknik Üniversitesi, Trabzon.

Çalık, M., Ayas, A. \& Ünal, S. (2006). Çözünme kavramıyla ilgili öğrenci kavramalarının tespiti: bir yaşlar arası karşılaştırma çalışması. Türk Ĕgitim Bilimleri Dergisi, 4(3), 309-322.

Çalık, M., Kolomuç, A. \& Karagölge, Z. (2010). The effect of conceptual change pedagogy on students' conceptions of rate of reaction. Journal of Science Education and Technology, 19(5), 422-433.

Demerouti, M., Kousathana, M. \& Tsaparlis, G. (2004). Acid-base equilibria: part I, upper secondary students, misconceptions and difficulties. The Chemical Educator, 9, 122131. 
Demircioğlu, G., Ayas, A. \& Demircioğlu, H. (2005). Conceptual change achieved through a new teaching program on acids and bases. Chemistry Education Research and Practice in Europe, 6(1), 36-51.

Demircioğlu, G., Özmen, H. \& Ayas, A. (2004). Some concepts misconceptions encountered in chemistry: a research on acid and base. Educational Sciences: Theory and Practice, 4(1), 73-80.

Drechsler, M. \& Van Driel, J. (2008). Experienced teachers' pedagogical content knowledge of teaching acid-base chemistry. Research in Science Education, 38(5), 611-631.

Driver, R. \& Easley, J. (1978). Pupils and paradigms: a review of literature related to concept development in adolescent science students. Studies in Science Education, 5, 61-84.

Ebenezer, J.V. \& Erickson, L.G. (1996). Chemistry students' conception of solubility: a phenomenograpy. Science Education, 80(2), 181-201.

Ebenezer, J.V. \& Gaskell, P.J. (1995). Relational conceptual change in solution chemistry, Science Education, 79(1), 1-17.

Fensham, P.J. (1988). Approaches to the teaching of STS in science education, International Journal of Science Education, 10(4), 346-356.

Finley, F.N., Stewart, J. \& Yarroch, W.L. (1982). Teachers' perceptions of 1mportant and difficult science content. Science Education, 66(4), 531-538.

Fishbane, P. M., Gasiorowicz, S. \& Thornton, S. T. (2003). Temel fizik, Cilt II, Çeviri: C. Yalçın, Arkadaş Yayınevi, Ankara.

Furio-Mas, C., Calatayud, L.M., Guisasola, J. \& Furio-Gomez, C. (2005). How are the concepts and theories of acid base reactions presented? chemistry in textbooks and as presented by teachers. International Journal of Science Education, 27, 1337-1358.

Garnett, P. L. \& Treagust D. F. (1992a). Conceptual Difficulties by Senior High School Students of Electrochemistry: Electric Circuits and Oxidation-Reduction Equations. Journal of Research in Science Teaching, 29(2), 121-142.

Garnett, P.L. \& Treagust, D.F. (1992b). Conceptual Difficulties Experienced by Senior High School Students of Electrochemistry: Electrochemical (Galvanic) and Electrolytic Cells. Journal of Research in Science Teaching, 29(10), 1079-1099

Gonzalez, F.M. (1997). Diagnosis of Spanish Primary School Students' Common Alternative Science Concepts. School Science and Mathematics, 97(2), 68-74. 
Griffiths, A.K. \& Preston, K.R. (1992). Grade-12 Students' Misconceptions Relating To Fundamental Characteristics of Atoms and Molecules. Journal of Research in Science Teaching, 29(6), 611-628.

Hackling, M. W. \& Garnett, P. J. (1985). Misconceptions of Chemical Equilibrium. European Journal of Science Education, 7(2), 205-214.

Haidar, A. H. \& Abraham, M. R. (1991). A Comparison of Applied and Theoretical Knowledge of Concept Based on the Particulate Nature of Matter. Journal of Research in Science Teaching, 28(10), 919-938.

Hand, B.M. \& Treagust, D.F. (1988). Application of a Conceptual Conflict Strategy to Enhance Student Learning of Acids and Bases. Research in Science Education, 18, 53-63.

Hazel, E. \& Prosser, M. (1994), “First-Year University Students' Understanding of Photosynthesis", Their Study Strategies and Learning Context. The American Biology Teacher, 56(5), 274-279.

Hwang, B.T. \& Hwang, H.W. (1990). A Study of Cognitive Development of the Concepts of Solution, Research Report, Taipei, Republic of China: National Science Council.

Kabapinar, F., Leach, J. \& Scott, P. (2004). The Design and Evaluation of a Teaching-Learning Sequence Addressing the Solubility Concept with Turkish Secondary School Students. International Journal of Science Education, 26(5), 635-652.

Kalın, B. \& Arıkıl, G. (2010). Misconceptions Possessed by Undergraduate Students about the Topic "Solutions". Necatibey Eğitim Fakültesi Elektronik Fen ve Matematik Eğitimi Dergisi (EFMED), 4(2), 177-206.

Karslı, F. (2011). Fen Bilgisi Öğretmen Adaylarının Bilimsel Süreç Becerilerini Geliştirmesinde ve Kavramsal Değişim Sağlamasında Zenginleştirilmiş Laboratuar Rehber Materyallerinin Etkisi. Yayınlanmamış Doktora Tezi. Karadeniz Teknik Üniversitesi, Trabzon.

Karslı, F. \& Çalık, M. (2012). Can Freshman Science Student Teachers’ Alternative Conceptions of 'Electrochemical Cells' Be Fully Diminished? Asian Journal of Chemistry, 23(12), 485-491.

Kautz, C.H., Heron, P.R.L., Loverude, M.E. \& McDermott, L.C. (2005). Student Understanding of the Ideal Gas Law, Part 1: A Macroscopic Perspective. American Journal of Physics, 73(11), 1055-1063.

Kolomuç, A. \& Tekin, S. (2011). Chemistry Teachers' Misconceptions Concerning Concept of Chemical Reaction Rate. Eurasian Journal of Physics and Chemistry Education, 3(2), 84-101. 
Kolomuç, A. (2009). 11.Sınıf Kimyasal Reaksiyonların Hızları Ünitesinin 5E Modeline Göre Animasyon Destekli Öğretimi. Doktora Tezi, Atatürk Üniversitesi, Erzurum.

Koray, Ö., Akyaz, N. \& Köksal, M.S. (2007). Lise Öğrencilerinin “Çözünürlük” Konusunda Günlük Yaşamla İlgili Olaylarda Gözlenen Kavram Yanılgıları. Kastamonu Eğitim Dergisi, 15(1), 241-250.

Liew, C.W. \& Treagust, D.F. (1998), “The Effectiveness of Predict-Observe-Explain Tasks in Diagnosing Students' Understanding of Science and in Identifying Their Levels of Achievement", Paper Presented at the Annual Meeting of The American Educational Research Association, San Diego.

Lin, H., Cheng, H. \& Lawrenz, F. (2000). The Assessment of Students and Teachers' Understanding of Gas Laws. Journal of Chemistry Education, 77(2), 235-238.

Marek, E.A. (1986). They Misunderstand, But They'll Pass. The Science Teacher, 32-35.

Maskill, R. \& Cachapuz, A.F.C. (1989). Learning about The Chemistry Topic of Equilibrium:

The Use of Word Association Tests to Detect Developing Conceptualizations, International Journal of Science Education, 11(1), 57-69.

Nakhleh, M.B. \& Krajcik, J.S. (1994). Influence of Levels of Information as Presented by Different Technologies on Students' Understanding of Acid, Base, and pH Concepts. Journal of Research in Science Teaching, 34(10), 1077-1096.

Nakhleh, M.B. (1992). Why Some Students Don’t Learn Chemistry: Chemical Misconceptions. Journal of Chemical Education, 69(3), 191-196.

Nakhleh, M.B. (1994). Students Models of Matter in the Context of Acid-Base Chemistry. Journal of Chemical Education, 71, 495-499.

Nakiboğlu, C., Benlikaya, R. \& Kalın, Ş. (2002). Kimya Öğretmen Adaylarının Kimyasal Kinetik ile İlgili Yanlış Kavramalarının Belirlenmesinde V-Diyagramının Kullanılması, V. Ulusal Fen Bilimleri ve Matematik Eğitimi Kongresi, ODTÜ, Eylül, Ankara.

Niaz, M., Aguilera, D., Maza, A. \& Liendo, G. (2002). Arguments, Contradictions, Resistances, and Conceptual Change in Students' Understanding of Atomic Structure, Science Education, 86, 505-525.

Ogude, A.N. \& Bradley, J.D. (1994). Ionic Conduction and Electrical Neutrality in Operating Electrochemical Cells, Journal of Chemical Education, 71(1), 29-34.

Osborne, R.J. \& Cosgrove, M.M. (1983). Children's Conceptions of the Changes of State of Water. Journal of Research in Science Teaching, 20, 825-838. 
Özden, M. (2009). Prospective Science Teachers' Conceptions of the Solution Chemistry, Journal of Baltic Science Education, 8(2), 69-78.

Özkaya, A.R. (2002). Conceptual Difficulties Experienced by Prospective Teachers in Electrochemistry: Half-Cell Potential, Cell Potential, and Chemical and Electrochemical Equilibrium in Galvanic Cells, Journal of Chemical Education, 79(6), 735-738.

Paik, S.H., Kim, H.N., Cho, B.K. \& Park, J.W. (2004). K-8th Grade Korean Students' 'Conceptions of Changes of State' and 'Conditions for Changes of State'. International Journal of Science Education, 26(2), 207-224.

Pınarbaş1, T. \& Canpolat, N. (2003). Students Understanding of Solutions Chemistry Concepts. Journal of Chemistry Education, 80(11), 1328-1332.

Pınarbaşı, T. (2002). Çözünürlük ile Illgili Kavramların Anlaşılmasında Kavramsal Değişim Yaklaşımının Etkinliğinin İncelenmesi. Doktora Tezi, Atatürk Üniversitesi, Erzurum.

Pınarbaşı, T. (2007). Turkish Undergraduate Students' Misconceptions on Acids and Bases. Journal of Baltic Science Education, 6(1), 23-34.

Prieto, T., Blanco, A. \& Rodriguez, A. (1989). The Ideas of 11 to 14-Year-Old Students About The Nature of Solutions. International Journal of Science Education, 11(4), 451-463.

Ross, B.H.B. \& Munby, H. (1991). Concept Mapping and Misconceptions: A Study of HighSchool Students' Understandings of Acids and Bases. International Journal of Science Education, 13(1), 11-23.

Sanger, M.J. \& Greenbowe T.J. (1999). An Analysis of College Chemistry Textbooks as Sources of Misconceptions and Errors in Electrochemistry: Galvanic, Electrolytic and Concentration Cells. Journal of Chemical Education, 76(6), 853-860.

Sanger, M.J. \& Greenbowe, T.J. (1997). Students' Misconceptions in E1ectrochemistry: Current Flow in Electrolytc Solutions and the Salt Bridge, Research. Science \& Education, 7(74), 819-823.

Schmidt, H.J., Marohn, A. \& Harrison, A.G. (2007). Factors That Prevent Learning in Electrochemistry. Journal of Research in Science Teaching, 44(2), 258-283.

Sheppard, K. (2006). High School Students' Understanding of Titrations and Related Acid-Base Phenomena. Chemisty Education: Research and Practice, 7, 32-45.

Smith, J.K. \& Metz, P.A. (1996), "Evaluating Student Understanding of Solution Chemistry Through Microscopic Representations”. Journal of Chemical Education, 73(3), 233235. 
Stavy, R. (1988). Children's Conception of Gas. International Journal of Science Education, 10(5), 553-560.

Sun, Y.C. (2009). Using a Two-Tier Test in Examining Taiwan Graduate Students' Perspectives on Paraphrasing Strategies. Asia Pacific Educational Review, 10, 399-408.

Şahin, Ç. \& Çepni, S. (2011). "Yüzme- Batma, Kaldırma Kuvveti ve Basınç" Kavramları ile İlgili İki Aşamalı Kavramsal Yapılardaki Farklılaşmayı Belirleme Testi Geliştirilmesi, Journal of Turkish Science Education (TUSED), 8(1), 79-110.

Şencan, H. (2005). Sosyal ve Davranışsal Ölçümlerde Güvenirlik ve Geçerlilik. Seçkin Yayıncılık, Ankara.

Taştan, Ö., Yalçınkaya, E. \& Boz, Y. (2010). Pre-Service Chemistry Teachers' Ideas About Reaction Mechanism. Journal of Turkish Science Education, 7(1), 47-60.

Tezcan, H. \& Bilgin, E. (2004). Liselerde Çözünürlük Konusunun Öğretimde Laboratuvar Yönteminin ve Bazı Faktörlerin Öğrenci Başarısına Etkileri. Gazi Üniversitesi Gazi Eğitim Fakültesi Dergisi, 24(3), 175-191.

Treagust, D.F. \& Chandrasegaran, A. L. (2007). The Taiwan National Science Concept Learning Study in an International Perspective. Journal of Science Education, 29(4), 391-403.

Treagust, D.F. (1988). Development and Use of Diagnostic Tests to Evaluate Students' Misconceptions in Science. International Journal of Science Education, 10(2), 159169.

Tüysüz, C. (2009). Development of Two-Tier Diagnostic Instrument and Assess Students' Understanding in Chemistry. Scientific Research and Essay, 4(6), 626-631.

Tytler, R. (2000). A Comparison of Year 1 and Year 6 Students' Conceptions of Evaporation and Condensation: Dimensions of Conceptual Progression. International Journal of Science Education, 22(5), 447- 467.

Uzuntiryaki, E. \& Geban, Ö. (2005). Effect of Conceptual Change Approach Accompanied With Concept Mapping on Understanding of Solution Concepts. Instructional Science, 33(3), 11-19.

Uzuntiryaki, E. (1998). Effect of Conceptual Change Approach Accompanied with Concept Mapping on Understanding of Solution. Doktora Tezi, O.D.T.Ü., Ankara.

Ünal, S. \& Coştu, B. (2005). Problematic Issue for Students: Does It Sink or Float? Asia Pacific Forum on Science Learning and Teaching, 6, 1, 3. 
Valanides, N. (2000). Primary Students Teachers' Understanding of the Particulate Nature of Matter and Its Transformations During Dissolving. Chemistry Education Research and Practice in Europe, 1(2), 249-262.

Varelas, M., Pappas, C.C. \& Rife, A. (2006). Exploring the Role of Intertextuality in Concept Construction: Urban Second Graders Make Sense of Evaporation, Boiling and Condensation. Journal of Research in Science Teaching, 43(7), 637-666.

White, R.T., \& Gunstone, R.F. (1992). Probing understanding. London; New York: Falmer Press.

Yıldırım A. \& Şimşek H. (2008) Sosyal Bilimlerde Nitel Araştırma Yöntemleri (7. Baskı) Ankara Seçkin Yayıncılık.

Y1lmaz, A., Erdem, E. \& Morgil, İ. (2002). Students' Misconceptions Concerning Electrochemistry. Hacettepe University Journal of Education, 23, 234-242.

Zoller, U. (1990). Students' Misunderstandings and Misconceptions in College Freshman Chemistry. Journal of Research in Science Teaching, 27(10), 1053-1065. 